\title{
H 108
}

○柴田 佳子、神部 眞理子、山本 蒔子 (JR仙台病院 保健管理部)

【目的】禁煙外来受診者の禁煙継続率等を調 査し, 禁煙外来の今後のありかたを考察する。 【方法】平成 6 年 11 月から平成 10 年 10 月 までの禁煙外来受診者 158 名,平均年齢 $47.3 \pm$ 11.4 (=S.D.) を対象に禁煙継続ができている か等のアンケート用紙を送付し, 無記名記入方 式で回答を得た。

【結果】男性 62 名、女性 2 名から回答を得た （回収率 $40.5 \%$ ）回答者の平均年齢は $51.4 \pm$ 12.6才で高齢者の割合が高かった(図 1 )。職業 については, 3分の 2 の者が会社員, 公務員だ った。21\%が無職であったが，その大半は退職 後の高齢者であった(図 2)。禁煙継続の有無 については, 外来受診後禁煙が継続している者 は40\%，一度喫煙したが再度禁煙中の者が $8.3 \%$ であった(図 3)。一方で禁煙に失敗し再喫煙 を始めた者が51.7\%を占めた。禁煙成功者の平 均禁煙年数は $1.9 \pm 1.2$ 年だったが, 禁煙を続け られている理由として，50\%がもう吸いたくな いから，49\%が自分の意志で頑張っているから， $1 \%$ 友人や家族の協力があるからと答えた

（図 4）。

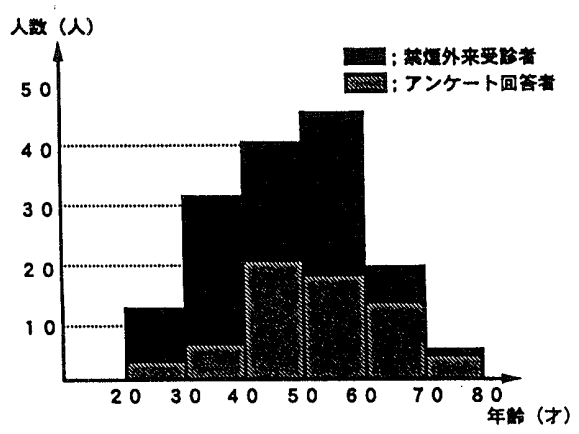

【图1】年代別禁煙外来受部者

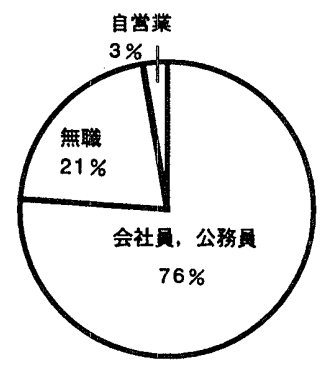

【図2】職莱別替煙外来受䩕者

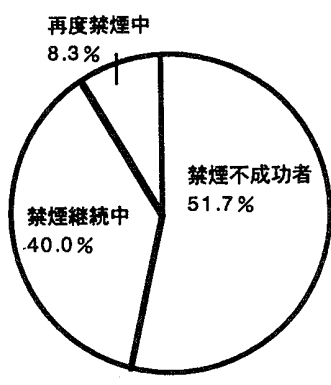

【図 3】禁煙継統の有無
一方禁煙不成功者の禁煙期間は平均 $5.2 \pm 7.7$ ヶ 月であり, 再喫煙の理由は, 仕事が忙しくスト レスがたまったためと答えた者が $45.7 \%$ ，飲酒 時に吸ってしまったと答えた者が40\%とほぼ2 分された。また，体重が増えたためと答えた者 は11.4\%であった。他人にすすめられたためと 答えた者は皆無であった。その他の理由の中で は眠れなかったためや家族が喫煙するので一緒 に吸ってしまった等の意見があった(図 5 )。 また再喫煙者に対してもう一度禁煙をしたいか 質問した結果，73\%が再度禁煙に挑戦したいと 答元た。

【考察】今回のアンケートより仕事のストレス 及びアルコールが禁煙継続の 2 大障害となって いることが明らかとなった。また禁煙を継続し ている人達の半数が自分の意志で頑張っている と答えていることより，禁煙者の半数は吸いた いという欲求を持ち続けている可能性があると 考えられる。しかし一方では禁煙不成功者の7 割が再度禁煙に挑戦したいと考えており，禁煙 外来受診を契機に禁煙意識が高まった効果と考 えられる。特に禁煙外来受診者は外からの働き かけを求めている場合が多いと考えられるので, 外来終了後も禁煙に関する相談空口を設置した り，その後の状況を定期的に通知してもらうよ うな制度を作ったりする等の積極的な介入を実 施した場合の効果も十分期待できるであろう。

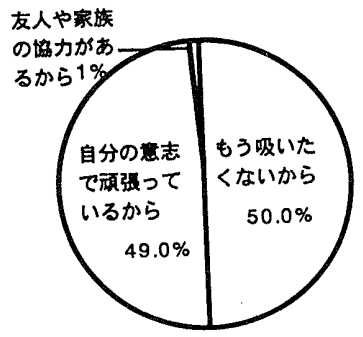

【図4】泶煙継続の理由

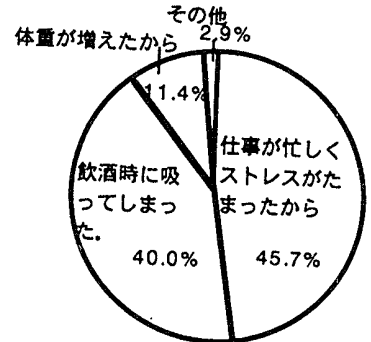

【図5】再嘹煙の理由 